\title{
Duplex-PCR assay for the detection of adenovirus and respiratory syncytial virus in nasopharyngeal samples
}

\author{
Juliana Cristina Marinheiro', Roberta Braga Sanalios' ${ }^{1}$, Daniela Carvalho dos Santos', \\ Cristovão Alves da Costa ${ }^{2}$, Charlotte Marianna Hársi ${ }^{1 /+}$
}

'Laboratório de Biologia Molecular de Adenovírus, Departamento de Microbiologia, Instituto de Ciências Biomédicas, Universidade de São Paulo, Av. Prof Lineu Prestes 1374, 05508-900 São Paulo, SP, Brasil ${ }^{2}$ Laboratório de Virologia Tropical, Instituto Nacional de Pesquisas da Amazônia, Manaus, AM, Brasil

Human adenovirus (HAdV) and human respiratory syncytial virus (HRSV) are important etiologic agents of acute respiratory infections. In this study, a duplex polymerase chain reaction (PCR) assay was developed for the simultaneous detection of HAdV and HRSV in clinical samples. Sixty previously screened nasopharyngeal aspirates were used: 20 HAdV-positive, 20 HRSV-positive and 20 double-negative controls. Eight samples were positive for both viruses. The duplex PCR assay proved to be as sensitive and specific as single-target assays and also detected the mixed infections with certainty. The identification of both viruses in a single reaction offers a reduction in both cost and laboratory diagnostic time.

Key words: human adenovirus - human respiratory syncytial virus - acute respiratory infection - polymerase chain reaction

Acute respiratory infections (ARI) are the third cause of morbidity and mortality in children and adults worldwide, with a particularly significant impact in developing countries. They are responsible for the death of four million people per year (WHO 2008). ARI are responsible for $20 \%-40 \%$ of infant hospitalizations (Hemming 1994, Vieira et al. 2001). Viruses are the major etiological agents of ARI, causing $45 \%-60 \%$ of all acute respiratory diseases in infants and young children (Canducci et al. 2008). Human respiratory syncytial virus (HRSV) is a major pathogen, causing several symptoms such as bronchiolitis and pneumonia (Calegari et al. 2005, Canducci et al. 2008). HRSV is the cause of hospitalization for approximately $45 \%$ of children under the age of two years (Avedaño et al. 1999, Schmidt et al. 2001, Vieira et al. 2001, Canducci et al. 2008). Human adenovirus (HAdV) represents $5 \%-15 \%$ of the viruses isolated from children less than two years of age that are hospitalized with ARI (Moura et al. 2007). Children with respiratory adenovirus may have a wide variety of symptoms, including pharyngitis, tonsillitis, pharyngoconjunctival fever, bronchitis and pneumonia (Palomino et al. 2000, Vieira et al. 2001). Laboratory diagnosis of respiratory viruses is frequently made by using an indirect immunofluorescent assay (IFA), but the sensitivity and specificity of this method is lower than viral culture or molecular detection methods (Räty et al. 1999). Polymerase chain reaction (PCR) is the most sensitive technique to detect these viruses in clinical samples such as nasopharyngeal aspirates (Osiowy 1998, Echavarria

Financial support: FAPESP (06/56482-0)

+ Corresponding author: chmharsi@icb.usp.br

Received 18 September 2008

Accepted 13 January 2009 et al. 2003, Larcher et al. 2006, Canducci et al. 2008). Knowing that HRSV and HAdV are important and frequent agents for ARI and that accurate diagnosis would be helpful for medical care, we propose a duplex PCR assay. The use of one reaction for simultaneous detection of both viruses offers a reduction in costs and shortened laboratory diagnosis time (Barenfanger et al. 2000).

HAdV prototypes from species B (HAdV-3) and species C (HAdV-5) originated from the Central Public Health Laboratory, London, UK. HRSV prototypes (HRSV-A2 and HRSV-B1) were received from the Central Public Health Laboratory, Atlanta, GA, USA. Viruses were cultivated in HEp2 cells (human larynx epithelial carcinoma) and titrated. Infective doses of prototypes were determined using the $\mathrm{TCID}_{50}(50 \%$ tissue culture infective dose) assay (Reed \& Muench 1938). Prototypes were used in the duplex PCR as positive controls at $200 \mathrm{TCID}_{50}$.

Nasopharyngeal aspirate samples were collected from children hospitalized with ARI in the city of Manaus, Amazonas, Brazil during 1999. Samples were collected following ethical standards, using a protocol approved by the Committee on Ethical on Human Experimentation of the Instituto de Ciências Biomédicas, Universidade de São Paulo (protocol 378/CEP). These samples had been previously screened for respiratory viruses by IFA using monoclonal antibodies (Chemicon International Inc, California, USA) and by single-target PCR assays. Adenoviruses DNA were detected using a generic PCR assay with a pair of primers directed to a conserved region of the hexon gene, which recognizes all 51 serotypes of HAdV (Xu et al. 2000). The sensitivity of the reaction was determined to be sufficient to detect a minimum of 0.1 TCID $_{50}$. HRSV species A and B RNA were detected with a pair of primers directed to the $\mathrm{F}$ and $\mathrm{G}$ proteins (Bosso et al. 2004). Sensitivity of the reverse transcription-PCR (RT-PCR) was determined to be sufficient to detect 6.59 TCID $_{50}$ of HRSV-A and 1.405 TCID $_{50}$ of HRSV-B (Nascimento et al. 2008). 
To test the duplex PCR, 60 clinical samples were selected: 20 positive for HRSV; 20 positive for HAdV (8 of these positive for both viruses); and 20 double negative controls. A $250-\mu \mathrm{L}$ aliquot of each crude sample was dispensed into a tube containing $750 \mu \mathrm{L}$ of Trizol ${ }^{\mathbb{R}}$ (Invitrogen $^{\mathrm{TM}}$ Brasil Ltda, São Paulo, Brazil). As a first step, RNA was extracted according to the manufacturer's suggested method. The Trizol phase was retained for subsequent DNA extraction. The extracted RNA was suspended in $25 \mu \mathrm{L}$ of diethylpyrocarbonate-treated water and immediately used in the RT reactions. For the cDNA synthesis, $50 \mu \mathrm{L}$ reactions were prepared by adding 25 $\mu \mathrm{L}$ of the extracted RNA to $25 \mu \mathrm{L}$ of a mix containing 1X RT Buffer, $200 \mathrm{mM}$ dNTP mixture, $1 \mathrm{X}$ of random primers and $2.5 \mathrm{U} / \mu \mathrm{L}$ MultiScribe ${ }^{\mathrm{TM}} \mathrm{RT}$ (all from Applied Biosystems Brazil, São Paulo, Brazil). Transcription reactions were performed at $25^{\circ} \mathrm{C}$ for $10 \mathrm{~min}$ and $37^{\circ} \mathrm{C}$ for $120 \mathrm{~min}$ on a Biometra $\mathrm{T} 3$ thermocycler. The cDNA was kept at $-20^{\circ} \mathrm{C}$. The DNA was extracted from the Trizol suspension of the crude sample by a modified Shinagawa et al. (1983) method. Briefly, the DNA was precipitated by adding $750 \mu \mathrm{L}$ of ethanol followed by centrifugation at $12,000 \mathrm{~g}$ for $15 \mathrm{~min}$. The pellet was suspended in Tris-TE buffer (10 mM Tris-HCl, $\mathrm{pH} 7.8$, $1 \mathrm{mM}$ EDTA) with $10 \% \mathrm{SDS}, 5 \% \mathrm{NaCl}$ and $10 \mathrm{mg} / \mathrm{mL}$ Proteinase K (Invitrogen Brasil Ltda, São Paulo, Brazil). After digestion at $60^{\circ} \mathrm{C}$ for $60 \mathrm{~min}$, viral DNA was extracted with phenol/chloroform-isoamyl alcohol (25/24:1) and precipitated with isopropanol. The extracted DNA was suspended in $100 \mu \mathrm{L}$ of Tris-TE buffer.

Duplex PCR was performed with $6 \mu \mathrm{L}$ of the cDNA and $4 \mu \mathrm{L}$ of the extracted DNA. The primers targeted the hexon gene of the adenoviruses: XuHex1: 5' -TTCCCCATGGCICAYAACAC-3 and XuHex2: 5' -CCCTGGTAKCCRATRTTGTA-3' (Xu et al. 2000); and to the $F$ and $G$ protein regions of the HRSV: FV: 5' -GTTATGACACTGGTATACCAACC-3' (Zheng et al. 1996) and GAB: 5' -YCAYTTTGAAGTGTTCAACTT-3' (TCT Peret, from CDC, Atlanta, USA, unpublished observations). The duplex PCR was performed with a mix of 1X PCR Buffer, $250 \mathrm{mM}$ of each dNTP, 10 pmol of each primer (FV, GAB, XuHex1 and XuHex2) and two units of Tth DNA polymerase (Biotools Brasil Ltda, Rio de Janeiro, Brazil). The thermocycling conditions were as follows: for $95^{\circ} \mathrm{C}$ for $5 \mathrm{~min}, 35$ cycles of $94^{\circ} \mathrm{C}$ for $1 \mathrm{~min}$, $54^{\circ} \mathrm{C}$ for $1 \mathrm{~min}$ and $72^{\circ} \mathrm{C}$ for $1 \mathrm{~min}$, and a final extension step at $72^{\circ} \mathrm{C}$ for $7 \mathrm{~min}$. The samples were loaded into $1.5 \%$ agarose gels in TAE buffer $(40 \mathrm{mM}$ Tris acetate, $1 \mathrm{mM}$ EDTA $\mathrm{Na}_{2}, \mathrm{pH}$ 8.5), subjected to electrophoresis and observed under UV light after staining in ethidium bromide. Images were recorded with the PhotoCaptMw program (Viller Lourmat, Marne-la-Vallée, France).

Routine laboratory tests are usually directed to a single etiological agent, and when the results are negative, samples are rarely tested for a second pathogen. The single-target PCR protocols for HAdV and HRSV were routinely in use in our laboratory. Having observed that the annealing temperatures of both reactions were similar, our next step was to evaluate the specificity and qual- ity of the primers for the absence of dimers and hairpins, using Premier Biosoft software (Premier Biosoft 1994). After adjusting the annealing temperature to $54^{\circ} \mathrm{C}$ and the volume of the templates to $6 \mu \mathrm{L}$ of cDNA and $4 \mu \mathrm{L}$ of DNA, the duplex PCR could unequivocally detect the single as well as the mixed infections. Amplicons of 428 bp and $653 \mathrm{bp}$ size were considered positive for HAdV and HRSV, respectively (Figure). The results obtained using the duplex PCR assay matched perfectly with the previous screening results obtained using the single-target protocols for HAdV and HRSV.

Laboratory diagnosis methods for the detection of respiratory viruses are important to guide treatment and assure clinical and financial benefits. The use of a rapid and sensitive method is fundamental to patient treatment, reducing hospitalization time and costs, as well as avoiding unnecessary use of antibiotics and reducing child mortality (Barenfanger et al. 2000). The two most frequently used methods in laboratory diagnosis of ARI are the IFA and enzyme-linked immunosorbent assay (ELISA), which are both based on antigen detection. These methods have low costs and are simple to execute but present low sensitivity (Räty et al. 1999, Barenfanger et al. 2000, Kuypers et al. 2006).

Molecular diagnosis techniques have been developed that have increased sensitivity over antigen detection (IFA or ELISA) or culture-based methods (Räty et al. 1999). These techniques are usually limited to the detection of a single respiratory virus per assay, preventing the detection of others for which testing was not requested, and thus missing dual infections.

HRSV and HAdV are the most frequently detected infectious agents related to severe acute respiratory disease in children less than two years of age, which demands long-term hospitalization and sometimes intensive care. A reliable duplex PCR assay could be beneficial in the diagnosis of ARI. The benefits are the time of reaction, low volume of specimen required, ability to detect inactivated viruses and, most importantly, the detection of dual infections. The duplex PCR for HRSV and HAdV developed in this study was as sensitive and

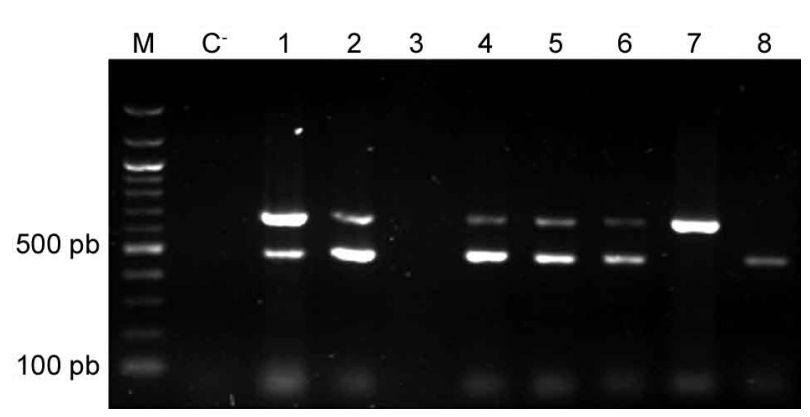

Duplex-PCR for the detection of human adenovirus (HAdV) and human respiratory syncytial virus (HRSV). Lanes M: molecular weight marker 100 bp ladder (GibcoBRL); $\mathrm{C}^{+}$: positive control; $\mathrm{C}^{-}$: negative control; 1, 2, 4-6: mixed samples (HRSV and HAdV); 3: negative sample; 7: HRSV prototype (conc. $200 \mathrm{TCID}_{50 \%}$ ); 8: HAdV prototype (conc. $200 \mathrm{TCID}_{50 \%}$ ). 
specific as the single-target reactions and accurately detected dual infections. Therefore, this assay provides a rapid and highly sensitive method for the simultaneous detection of the two major respiratory pathogens in infants and hastens clinical treatment decisions.

\section{REFERENCES}

Avedaño LF, Céspedes A, Stecher X, Palomino MA 1999. Influencia de virus respiratorios, frio y contaminación aérea en la infección respiratoria aguda baja del lactante. $R$ Med Chile 127: 1073-1078.

Barenfanger J, Drake C, Leon N, Mueller T, Troutt T 2000. Clinical and financial benefits of rapid detection of respiratory viruses: an outcomes study. J Clin Microbiol 38: 2824-2828.

Bosso PAR, Candeias JMG, Paduan KS, Ricchetti SMQ, Miranda AFM, Rugolo LMS, Durigon EL, Ventura AM 2004. Human respiratory syncytial virus detection in children admitted at a community hospital in Botucatu, SP, Brazil. Braz J Microbiol 35: 348-351.

Calegari T, Queiroz DAO, Yokosawa J, Silveira HL, Costa LF, Oliveira TFM, Luiz LN, Oliveira RC, Diniz FC, Rossi LMG, Carvalho CJ, Lima AC, Mantese OC 2005. Clinical-epidemiological evalution of respiratory syncytial virus infection in children attended in a public hospital in midwestern Brazil. Braz J Infect Dis 9: 156-161.

Canducci F, Debiaggi M, Sampaolo M, Marinozzi MC, Berrè S, Terulla C, Gargantini G, Cambieri P, Romero E, Clementi M 2008. Two-year prospective study of single infections and co-infections by respiratory syncytial virus and virus identified recently in infants with acute respiratory disease. J Med Virol 80: 716-723.

Echavarria M, Sanchez JL, Kolavic-Gray SA, Polyak C, RaymundoMitchell F, Innis BL, Vaughn D, Reynolds R, Binn LN 2003. Rapid detection of adenovirus in throat swab specimens by PCR during respiratory disease outbreaks among military recruits. J Clin Microbiol 41: 810-812.

Hemming VG 1994. Viral respiratory disease in children: classification, etiology, epidemiology and risk factors. J Pediatr 124: S13-6.

Kuypers J, Wright N, Ferrenberg J, Huang ML, Cent A, Corey L, Morrow R 2006. Comparison of real-time PCR assays with fluorescent-antibodies assays for diagnosis of respiratory virus infections in children. J Clin Microbiol 44: 2382-2388.

Larcher C, Jeller V, Fischer H, Huemer HP 2006. Prevalence of respiratory viruses, including newly identified viruses, in hospitalized children in Austria. Eur J Cli Microbiol Infect Dis 25: 681-686.

Moura PO, Roberto AF, Hein N, Baldacci E, Vieira SE, Ejzenberg B, Perrini P, Stewien KE, Durigon EL, Mehnert DU, Hársi CM
2007. Molecular epidemiology of human adenovirus isolated from children hospitalized with acute respiratory infection in São Paulo, Brazil. J Med Virol 79: 174-181.

Nascimento CA, Leal AL, Souza TS, Moraes CTP, Comone P, Tenório ECN, Vedocello D, Quinzani RHA, Gilio AE, Vieira SE, Durigon EL, Botosso VF, Sant'Anna OA 2008. One-step reverse transcriptase polymerase chain reaction for the diagnosis of respiratory syncytial virus in children. $J$ Virol Met 148: 115-119.

Osiowy C 1998. Direct detection of respiratory syncytial virus, parainfluenza virus and adenovirus in clinical respiratory specimens by a multiplex reverse transcription-PCR assay. J Clin Microbiol 36: 3149-3154.

Palomino MA, Larraña C, Avedaño LF 2000. Hospital-acquired adenovirus $7 \mathrm{~h}$ infantile respiratory infection in Chile. Pediatr Infect Dis 19: 527-531.

Premier Biosoft 1994. Premier Biosoft International, California [updated 2004 june]. Available from: www.premierbiosoft.com.

Räty R, Kleemola M, Melén K, Stenvik M, Julkunen I 1999. Efficacy of PCR and other diagnostic methods for detection of respiratory adenoviral infections. J Med Virol 59: 66-72.

Reed LJ, Muench H 1938. A simple method of estimating fifty percent endpoints. Am J Hyg 27: 493-497.

Schmidt AC, Couch RB, Galasso GJ, Hayden FG, Mills J, Murphy BR, Chanock RM 2001. Current research on respiratory viral infections: Third International Symposium. Antiviral Res 50: 157-196.

Shinagawa M, Matsuda A, Ishiyama T, Sato G 1983. A rapid and simple method for preparation of adenoviruses DNA from infected cells. Microbiol Immunol 27: 817-822.

Vieira SE, Stewien KE, Queiroz DA, Durigon EL, Torok TJ, Anderson LJ, Miyao CR, Hein N, Botosso VF, Pahl MM, Gilio AE, Ejzenberg B, Okay Y 2001. Clinical patterns and seasonal trends in respiratory syncytial virus hospitalization in São Paulo, Brazil. Rev Ins Med Trop Sao Paulo 43: 125-131.

WHO - World Health Organization 2008. World Health Statistics 2008. [updated August 2008]. Available from: www.who.int/ infectious-disease-report.

Xu W, McDonough MC, Erdman DD 2000. Species-specific identification of human adenoviruses by a multiplex PCR assay. J Clin Microbiol 38: 4114-4120.

Zheng H, Peret TC, Randoph VB, Crowley JC, Anderson LJ 1996. Strain-specific reverse transcriptase PCR assay: means to distinguish candidate vaccine from wild-type strains of respiratory syncytial virus. J Clin Microbiol 34: 334-337. 